\title{
Occurrence of detrital monazite within the Esva watershed (NW Spain): EPMA dating and REE geochemistry
}

\author{
SANTIAGO G. NISTAL ${ }^{1}$, RODRIGO ÁLVAREZ ${ }^{1 *}$, \\ ALMUDENA ORDÓÑEZ ${ }^{1}$, JORGE LOREDO ${ }^{1}$
}

${ }^{1}$ Mining exploration and explotation Department, University of Oviedo, School of Mines, Independencia St 13, 33004 (Spain) $(*$ corresponding author:

alvarezrodrigo@uniovi.es)

The Navia-Alto Sil (NASD) domain, an under-explored area, is a part of the so-called West-Asturian Leonese Zone (WALZ), which is located in the NW of the Iberian Massif (west-end outcrop of the European Variscides). This wide area $\left(\sim 3,500 \mathrm{~km}^{2}\right)$ is mainly drained by three watercourses (from west to east): Eo, Navia and Esva. The presence of detrital monazite has been identified in the three river mouths, particularly in that of the Esva, whose drainage basin extends $465 \mathrm{~km}^{2}$, where the highest monazite proportions in coastal sands were found. Since Rare Earth Elements (REEs) are considered as critical raw materials in relation with emerging technologies, attention has been paid to this finding.

The NASD is geologically constituted by a thick sequence of lower Palaeozoic rocks (mainly sandstones, quartzites and shales with a thin limestone horizon) that lies uncomformably over Precambrian slates. Small-size igneous bodies (granites, diabases, etc) can be found disperse within the metasedimentary record. Detrital monazite appears both as liberated sub-rounded individual grains $(100-150 \mu \mathrm{m}$ of diameter) and as mineral inclusions $(5-20 \mu \mathrm{m})$ hosted in metapelitic rock fragments without showing any chemical zoning.

In order to identify the monazite source, some electronprobe micro analysis (EPMA) were carried out over monazite grains from the Esva watershed. Mean $\Sigma \mathrm{RE}_{2} \mathrm{O}_{3}$ in the monazite is $70.03 \%$; it is enriched in Ce-La-Nd with minor quantities of heavy rare earth elements (from Eu to Lu, including Y), usually below $1 \%$ wt. EPMA dating by the $(\mathrm{U}, \mathrm{Th}) / \mathrm{Pb}$ method [1] indicates a Precambrian (Archean) age ( $\sim 3$ Gy), showing the existence of subsequent remobilization processes.

[1] Williams, ML., Jercinovic, MJ and CJ Hetherington, 2007. Microprobe monazite geochronology: Understanding geologic processes by integrating composition and chronology. Annual Review of Earth and Planetary Sciences, 35(1): $137-175$. 